\title{
Hybrid and Environmental Effects on Gene Expression in Poplar Clones in Pure and Mixed with Black Locust Stands
}

\author{
Oleksandra Kuchma ${ }^{1,2}{ }^{\oplus}$, Dennis Janz ${ }^{3}$, Ludger Leinemann ${ }^{1}$, Andrea Polle ${ }^{2,3}{ }^{(}$, \\ Konstantin V. Krutovsky ${ }^{1,2,4,5,6, * \mathbb{D}}$ and Oliver Gailing ${ }^{1,2, * \mathbb{D}}$ \\ 1 Department of Forest Genetics and Forest Tree Breeding, Georg-August University of Göttingen, \\ Büsgenweg 2, 37077 Göttingen, Germany; okuchma@gwdg.de (O.K.); lleinem@gwdg.de (L.L.) \\ 2 Center for Integrated Breeding Research (CiBreed), Georg-August University of Göttingen, \\ Albrecht-Thaer-Weg 3, 37075 Göttingen, Germany; apolle@gwdg.de \\ 3 Department of Forest Botany and Tree Physiology, Georg-August University of Göttingen, Büsgenweg 2, \\ 37077 Göttingen, Germany; djanz@gwdg.de \\ 4 Laboratory of Population Genetics, N. I. Vavilov Institute of General Genetics, Russian Academy of Sciences, \\ 119333 Moscow, Russia \\ 5 Laboratory of Forest Genomics, Genome Research and Education Center, \\ Institute of Fundamental Biology and Biotechnology, Siberian Federal University, \\ 660036 Krasnoyarsk, Russia \\ 6 Department of Ecosystem Science and Management, Texas A\&M University, 2138 TAMU, \\ College Station, TX 77843-2138, USA \\ * Correspondence: konstantin.krutovsky@forst.uni-goettingen.de (K.V.K.); ogailin@gwdg.de (O.G.); \\ Tel.: +49-551-39-33536 (O.G.)
}

Received: 4 September 2020; Accepted: 5 October 2020; Published: 8 October 2020 updates

\begin{abstract}
Mixed cropping might be seen as an alternative to monocultures by better protecting biodiversity and improving ecosystem services and resources. In the presented study, we tested the genetic and ecological effects of pure and mixed propagation of different poplar hybrids planted together with black locust trees. Poplar (Populus) hybrids are widely used for bioenergy in monoculture systems due to their rapid and high biomass production. Black locust (Robinia pseudoacacia L.) is a species with the ability to fix nitrogen and seen as a promising candidate for mixed cultivation. Eight different poplar hybrids and black locust trees from three provenances planted in two study sites with different environmental conditions were tested in varying combinations in pure and mixed stands to observe effects of the different hybrids and genotypes, site conditions and the mixed growing on the performance of poplar and its gene expression. Transcriptome analyses of leaves from four poplar clones selected according to their divergent growth performance were conducted to study differential gene expression that can be an important indicator of differences in growing conditions and success. Differences in gene expression were most pronounced among hybrids and different genotypes of the same hybrid, followed by the study site influence, and were least pronounced between mixed and pure stands. The genotypes of the same hybrid were clearly separated from each other. Clear separation between the study sites for all clones was also observed. Only a few genes were differently expressed in pure vs. mixed stand comparisons for each clone, but there were no common genes that were differently expressed in pure vs. mixed stands in all clones. In total, 199 genes showed differential expression between the study sites regardless of poplar clone or type of stands. The analysis suggested that plant genotypes and environmental conditions were more important at the early stage of stand development than pure or mixed cultivation.
\end{abstract}

Keywords: black locust; differentially expressed genes; mixed stands; monoculture; poplar; transcriptome 


\section{Introduction}

The growing need for biomass production leads to intensification of land use systems. Most of the economically important species used in agriculture and forestry are grown in monocultures. However, monoculture systems are well-known for their negative consequences for ecosystems resulting in soil degradation and salinization, loss of biodiversity, pollution by fertilizers and herbicides [1-3]. In this regard, mixed plant systems based on species with complementary traits could become a sustainable, economically beneficial and ecologically safe alternative or replacement for monocultures [4]. Positive effects of mixed stands for woody species have been demonstrated for Norway spruce, European beech, sessile oak and poplar hybrids [5-10].

Poplar hybrids (Populus) are widely used for bioenergy production in monoculture systems due to their rapid growth and high biomass production. Black locust (Robinia pseudoacacia L.) is usually not used for energy production, but is known for its ability to fix nitrogen. Moreover, black locust performs well under drought stress and on poor soils [11,12] and has already been tested in mixed stands with poplar [13-15]. Mixing of these two species may potentially improve ecological functions and enhance stand stability.

The fully sequenced and annotated genome of black cottonwood, Populus trichocarpa [16], promoted further transcriptome studies of poplar and other tree species for a better understanding of gene functions of perennial plants in response to their growing environment [17,18]. Since then, many transcriptome studies have been performed with different tree species to investigate their responses to different types of abiotic and biotic stress (e.g., [19-25]).

Importance of genotype by environment interactions for establishment of plantations has been recognized and demonstrated much earlier [4]. Studies conducted with poplar, eucalyptus and black locust species or hybrids [9,11,26-29] clearly showed an effect of local conditions on performance and productivity of the genotypes. Many transcriptome studies of plants growing under field conditions were performed for Arabidopsis, rice and maize (see [30] for review), but less for poplar [31-34].

In the present study, we report the first results for four Populus leaf transcriptomes. Experimental plots were established in two ecologically different sites to observe the influence of the clone, environmental conditions and mixed vs. monoculture cultivation on development of the stands [35]. The following hypotheses were tested in our study: (1) poplar clones respond differently to the planting design; (2) study site conditions influence the performance of stands; (3) the interaction between poplar and black locust trees is weak at the early stage of stand development.

\section{Materials and Methods}

\subsection{Experimental Design and Sampling}

To test for differences in the growth performance of eight commercially used poplar clones in monoculture and mixture with three black locust provenances, poplar cuttings and black locust seedlings were planted at two ecologically different study sites near Göttingen, Germany in April 2014 (Table 1). The poplar clones and hybrid-clones are well described [36,37] and known for establishing plantations, and were provided by WSD Energieholzbaumschule Björn Diehl (Oberaula, Germany), Staatsdarre Wolfgang (Hanau-Wolfgang, Germany) and P\&P Dienstleistungs GmbH Co KG (Eitelborn, Germany). Clonal identity was confirmed by microsatellite analyses. The R3 black locust seedlings (Nagybudmry, Hungary) were purchased under the German legislation of forest reproductive material from P\&P Dienstleistungs GmbH Co KG. The two German provenances (R1 and R2) originate from two different provenance regions in Germany and were provided by August Lüdemann (Frankfurt, Germany). One of the study sites, Reinshof, has a young fertile soil with high water storage capacity of Gleyic Fluvisol type (according to the FAO classification), a mean annual temperature of $9.7^{\circ} \mathrm{C}$ and an average annual precipitation of $453 \mathrm{~mm}$ measured in 2016 by on-site station Adolf Thies GmbH \& Co. KG (Goettingen, Germany). The other site, Deppoldshausen, is characterized by the shallow $(<60 \mathrm{~cm}$ deep) and stony soil with low ability to hold water of Calcaric Leptosol type (according to the FAO 
classification), a mean annual temperature of $9.0^{\circ} \mathrm{C}$ and an average annual precipitation of $457 \mathrm{~mm}$ measured in 2016 by on-site station Adolf Thies GmbH \& Co. KG (Goettingen, Germany). During the observation period 2015-2016, rainfall and mean annual temperature were lower in Deppoldshausen than in Reinshof (for the weather data see [35]).

Table 1. Poplar clones and black locust provenances used in the study.

\begin{tabular}{ccc}
\hline Name & Abbreviation & Species or Hybrid \\
\hline \multicolumn{3}{c}{ Poplar clones } \\
\hline AF2 & P1 & Populus deltoides $\times$ P. nigra \\
Fritzi Pauley & P2 & P. trichocarpa \\
Hybride 275 & P3 & P. maximowiczii $\times$ P. trichocarpa \\
I214 & P4 & P. deltoides $\times$ P. nigra \\
Matrix 11 & P5 & P. maximowiczii $\times$ P. trichocarpa \\
Matrix 49 & P6 & P. maximowiczii $\times$ P. trichocarpa \\
Max 1 & P7 & P. nigra $\times$ P. maximowiczii \\
Muhle Larsen & P8 & P. trichocarpa \\
\hline & Black locust provenances \\
\hline HGK 81901, Germany & R1 & Robinia pseudoacacia \\
HGK 81902, Germany & R2 & R. pseudoacacia \\
Nagybudmry, Hungary & R3 & Rseudoacacia \\
\hline
\end{tabular}

Four blocks (repetitions) were established at each study site (Figure S1). The design of the four blocks was exactly the same at each site. Each block consisted of 40 plots ( 8 rows $\times 5$ columns). The area of each plot was $5 \mathrm{~m} \times 5 \mathrm{~m}$, with 25 trees per plot in total in pure stands and 13 poplar and 12 black locust trees in mixed stands. In each row, one out of the eight poplar clones was planted in a pure plot and in three plots each, mixed with one of the three black locust provenances (Table S1). One of the plots in each row was a pure black locust provenance. Each of the four blocks (repetitions) at one site consisted of the same 40 plots with a random distribution within and between the rows. During the vegetation periods of 2014 and 2015, the growth and survival rates of all poplar clones and black locust provenances were measured [35].

For transcriptome analyses, four clones were selected: two clones "Hybride 275" and "Matrix 11" (P3 and P5, P. maximowiczii $\times$ P. trichocarpa) with an intermediate performance in terms of survival and growth, one "Max 1" (P7, P. nigra $\times$ P. maximowiczii) with the best performance, and one "Muhle Larsen" (P8, P. trichocarpa) with the worst performance [35]. Only stands with Robinia "HGK 81901" (R1) were selected. The black locust provenances "HKG81901" (R1) and "HKG81902" (R2) showed no significant differences in their performance in terms of mortality and growth [35], thus, they were handled as one provenance throughout the whole experiment. It was observed that bud burst of the P8 clone occurred about two weeks later in comparison to the three other clones. In addition, leaves of clone P8 are covered with oily, strong smelling balsam resin. Fresh young leaves from the middle part of a tree were collected and immediately frozen in the field in liquid nitrogen in May 2016 and stored at $-60{ }^{\circ} \mathrm{C}$ until RNA extraction. Samples were collected from three clonal trees per plot, in all four repetitions and both study sites resulting in 12 samples per clone in pure and mixed with Robinia "HGK 81901" stands per study site.

\subsection{RNA Extraction}

Total mRNA was extracted from 192 deeply frozen poplar leaf samples $(4$ clones $\times 2$ sites $\times 2$ types of stands (pure and mixed) $\times 12$ ramets) using the QIAGEN RNeasy Plant Mini Kit (Cat No./ID: 74904; QIAGEN GmbH, Hilden, Germany) and following the manufacturer protocol. Quality of each RNA sample was tested with NanoDrop 2000 (Thermo Fisher Scientific, Waltham, MA, USA) and in $1 \%$ agarose gel electrophoresis with $1 \mathrm{X}$ TAE as a running buffer. The high quality RNA from five to 
12 samples per clone, site and stand representing all four repetitions was pooled to generate 16 mixed equimolar samples that were submitted for RNA sequencing. Some amount of the extracted RNA was stored for further gene expression validation using quantitative real-time reverse transcription PCR (qRT-PCR). In total, 16 mixed samples ( 4 clones $\times 2$ types of stands $\times 2$ sites) were prepared and sequenced.

\subsection{RNA Sequencing}

Library preparation and sequencing of all samples were done by Chronix Biomedical GmbH (Göttingen, Germany). Additional quality control of RNA was performed with an Agilent 2100 Bioanalyzer (Agilent Technologies, Santa Clara, CA, USA). The cDNA libraries were prepared using the NEBNext Ultra RNA Library Prep Kit for Illumina (New England BioLabs, Frankfurt am Main, Germany). The samples were sequenced using the Illumina NextSeq500 Platform (Illumina, San Diego, CA, USA), which produced read lengths of $75 \mathrm{bp}$. RNA-seq data have been deposited in the ArrayExpress database at EMBL-EBI under accession number E-MTAB-9041.

The obtained RNA sequencing reads were mapped to the P. trichocarpa transcriptome from Phytozome 12.1 (www.phytozome.net; [38]) using the CLC Genomics Workbench 9.5.4 (CLCbio, Aarhus, Denmark). Trimming for quality and ambiguity of the raw sequence reads were conducted with quality scores (QS) $\geq 30$ and default settings of the CLC program. The raw sequence data were processed using fastq [39] with default parameters in $\mathrm{R}$ [40]. To check whether the different genetic backgrounds of the clones had an influence on the mapping results and, therefore, on the principal component analysis (PCA) clustering pattern, mapping approaches with differing sensitivity settings (fast and sensitive in Bowtie2 [41], in addition to the default) were tested.

\subsection{Principal Component Analysis (PCA)}

To check for the success of the RNA sequencing and to visualize the grouping of the poplar samples according to clone, type of stand or study site, a PCA was performed. Transcripts with a mean read number below five were not included in the analysis. The PCA was performed using the prcomp function of the stats program and displayed using the ggbiplot program [42] in the R package version 3.4.3 [40].

\subsection{Identification of Differently Expressed Genes (DEGs) and Sequence Annotation}

The analysis of differentially expressed genes (DEGs) among clones, between environments, and pure and mixed stands was performed using the "empirical analysis of DGE" (edgeR) algorithm [43] implemented in the CLC Genomics Workbench program.

Transcripts with at least five mapped reads on average per sample, a false discovery rate $($ FDR $)<0.1$ [44] and a $\log _{2}$ fold change $\geq 1$ were considered to be differently expressed. The poplar gene sequence matches for the DEGs and gene ontology (GO) terms [45] were obtained from Phytozome 12.1 and TAIR (The Arabidopsis Information Resource; http://www.arabidopsis.org) databases [46].

\subsection{Quantitative Real-Time Reverse Transcription PCR (qRT-PCR)}

qRT-PCR was performed to validate differences in gene expression levels. In total, 16 mixed samples were used for the qRT-PCR validation. The cDNA synthesis was performed with 500 ng RNA using the SuperScript III First-Strand Synthesis System for qRT-PCR (Invitrogen, Carlsbad, CA, USA) and Oligo(dT)20 primer (Sigma-Aldrich, Darmstadt, Germany). Three technical replicates for each mixed sample and one housekeeping gene were amplified with a TOptical Gradient 96 Real-Time PCR Thermocycler (Biometra, Analytik Jena, Jena, Germany). Actin 2 was used as a reference housekeeping gene [47].

Two Kunitz trypsin inhibitor genes PtiKPI-A1 (Potri.010G007700) and PtiKPI-A5 (Potri.010G007900) showing strong differences in the expression levels across clones between pure and mixed stands and the study sites were selected for validation (Table S2). The gene specific PCR primers were designed using Primer-BLAST [48] and the corresponding gene sequences from the CLC Genomics Workbench. 
These primer sequences were aligned using BioEdit 7.2.5 [49] and checked for self-complementarity using OligoCalc 3.27 [50].

The qRT-PCR mix included $4 \mu \mathrm{L}$ HPCL-grade $\mathrm{H}_{2} \mathrm{O}, 10 \mu \mathrm{L}$ innuMIX qPCR DSGreen Standard (Analytik Jena, Jena, Germany), $2.5 \mu \mathrm{L}$ of forward and reverse primers ( $5 \mathrm{pmol} / \mu \mathrm{l}$ ) and $1 \mu \mathrm{L}$ diluted cDNA (1:10). The PCR program was run with the following steps: pre-incubation for 3 min at $95^{\circ} \mathrm{C}$, 45 cycles of amplification for $5 \mathrm{~s}$ at $95^{\circ} \mathrm{C}, 5 \mathrm{~s}$ at $58^{\circ} \mathrm{C}$ and $15 \mathrm{~s}$ at $72{ }^{\circ} \mathrm{C}$. Primer efficiencies for the analyzed genes were evaluated by dilution series. Relative gene expression was calculated with the $2^{-\Delta \Delta \mathrm{C}(\mathrm{T})}$ method [51].

\section{Results}

\subsection{RNA Sequencing Data and Transcriptome Annotation}

The sequencing of the 16 poplar samples resulted in $396,683,782$ nucleotide reads after quality trimming, in total, ranging from 20,969,568 to $29,090,127$ reads per individual library $(24,792,736$ reads on average; Table S3).

Mapping success to the P. trichocarpa transcriptome varied from 80.3 to $90.9 \%$ ( $86.2 \%$ on average). Average coverage per gene varied from 20.4 to $28.3 \mathrm{X}$ (23.4X on average; Table S3). According to the mapping results, reads of $P$. nigra $\times$ P. maximowiczii hybrid P7 clone samples had better mapping to the P. trichocarpa transcriptome than reads of pure P. trichocarpa P8 clone. The mapping was repeated and the results were confirmed.

\subsection{Principal Component Analysis (PCA)}

PCA showed a clear separation among all four clones: the three hybrid clones P3 and P5 (P. maximowiczii $\times$ P. trichocarpa) and P7 (P. nigra $\times$ P. maximowiczii) and pure black cottonwood species clone P8 (P. trichocarpa) (Figure 1). It was notable that two different genotypes of the hybrid clones P3 and P5 were also clearly separated from each other. A clear separation of the two study sites, Reinshof and Deppoldshausen was observed within all hybrid clusters. The lowest level of separation was observed between pure and mixed stands for each poplar genotype and study site. The same hybrids (P3 and P5) showed a consistent pattern. Clone P7 demonstrated a different pattern in the separation of pure and mixed samples in both study sites: almost no differences were observed between pure and mixed samples in Reinshof, whereas the maximum distance among all other comparisons was observed between pure and mixed samples for clone P7 in Deppoldshausen.

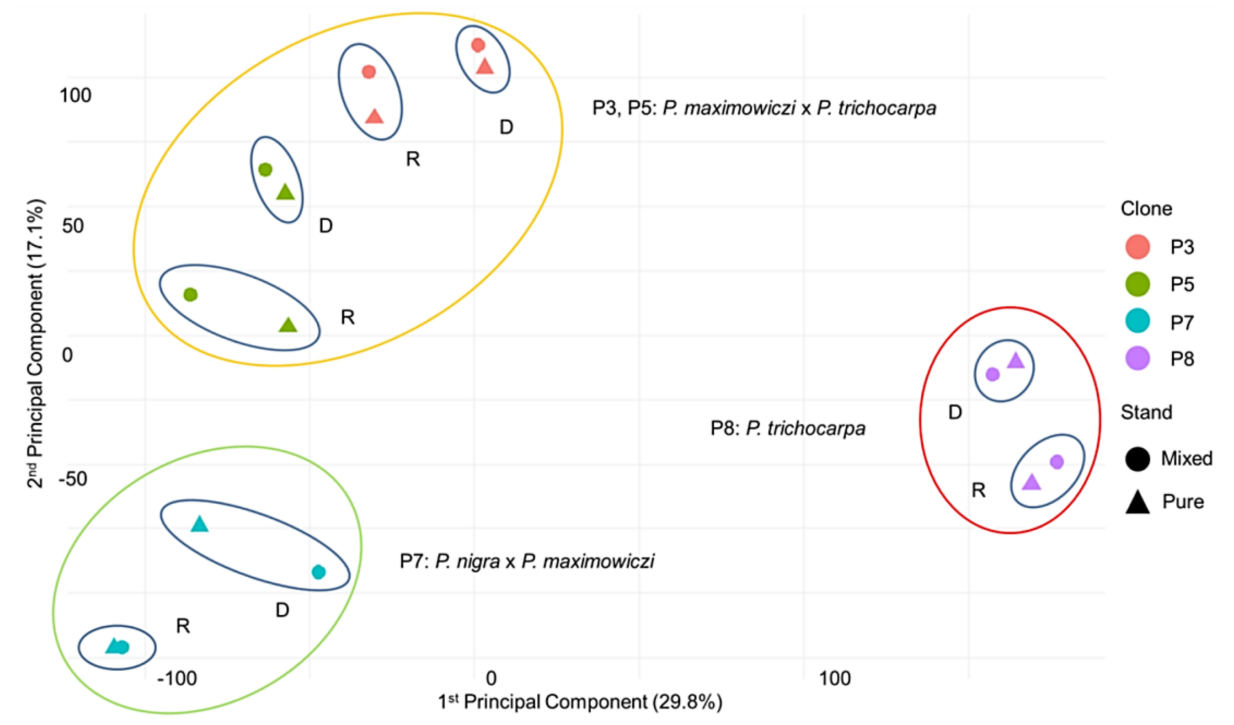

Figure 1. Principal component analysis (PCA) based on annotated transcripts in 16 mixed poplar samples; R-Reinshof, D-Deppoldshausen. 
Similar or almost identical clustering results were obtained using different sequence matching sensitivity settings for mapping, which indicated that the clustering together of samples from each of the hybrids was not only due to sequence similarity or dissimilarity between the hybrids (Figure S2).

\subsection{Differentially Expressed Genes (DEGs) Analyses}

Detailed comparisons of DEGs among clones were not performed. This is due to differing sequence similarities between the clones and Populus trichocarpa, which provides the mapping background. Therefore, differences in mapping effectivity would be detected and taken for differences in expression; since these differences will vary in all likelihoods from gene to gene, tests between clones cannot be calculated reliably. For the PCA overview, this was checked by conducting PCAs for different count tables obtained by varying mapping sensitivity settings. On an individual gene level, verification is not possible since full sequence information is not available for all hybrids.

The lack of clustering for mixed vs. pure stands in the PCA was in agreement with the results of the differential gene expression analysis. No common DEGs were identified in the total pure vs. mixed comparison under our experimental conditions and limited numbers of replicates. Nevertheless, this reflects low effects of the heterospecific neighbor (black locust) in the poplar stands at this stage of plantation development and high genetic variability between clones. Single clone pure vs. mixed comparisons for each study site separately could not be performed due to the lack of replicates within each genotype for sufficient statistical power to identify clone-specific interactions. By combining the samples from the two study sites, we could perform the comparison of pure vs. mixed stands for each single clone. These revealed genes that are influenced by the type of stand independently from the study site conditions. In total, 30 genes showed differential expression between pure and mixed samples (Table 2). Only two genes were common in the data set across clones_Potri.017G025900 in P7 and P8 with opposite expression behavior, and Potri.001G441400 in P3 and P7. In each comparison, stress and/or defense response genes were detected as DEGs and showed lower expression levels in the mixed stands.

According to the PCA, the second strongest clustering after the differences between hybrids was the clustering for study sites. To evaluate the influence of a study site on clone performance we compared the complete sample sets of Deppoldshausen vs. Reinshof. In total, 199 genes showed differential expression between the two study sites in combined comparisons regardless of clone or type of stands (pure vs. mixed) (Table S4). Among them, 119 genes showed higher expression levels in Deppoldshausen and 80 in Reinshof.

The study site comparisons were also performed for each clone separately. The highest number of DEGs between the study sites was observed for clone P7 with total of 1706 genes, and similar numbers were observed for other clones (Table 3, Tables S5 and S6).

Table 2. Differentially expressed genes (DEGs) in pure vs. mixed sample comparisons for each clone regardless of study site.

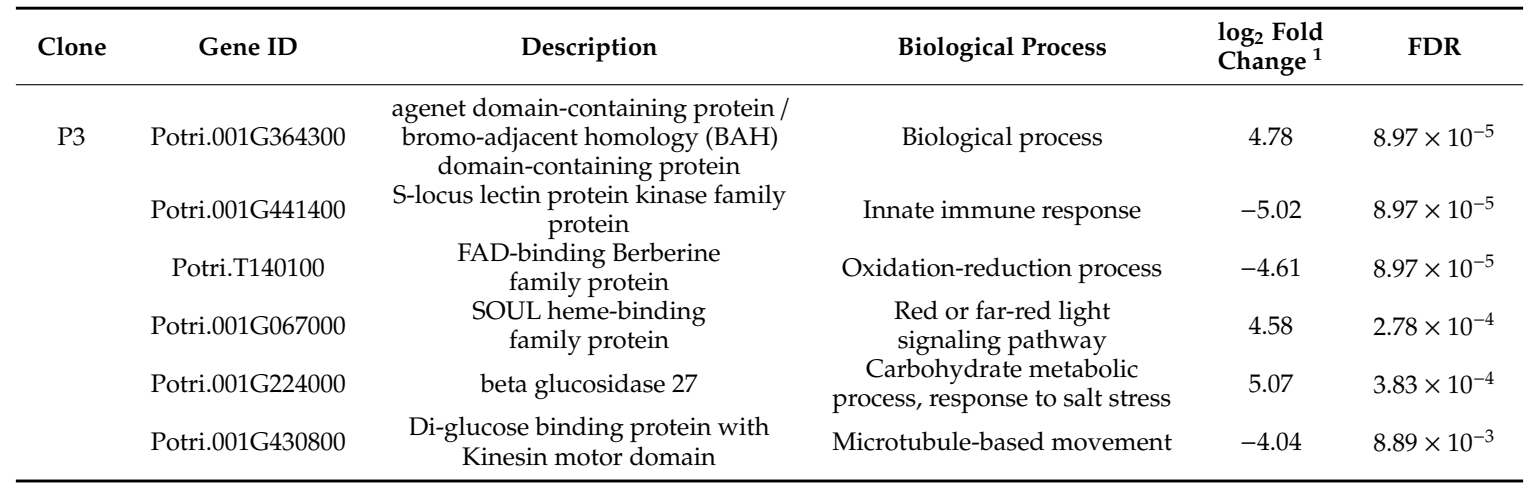


Table 2. Cont.

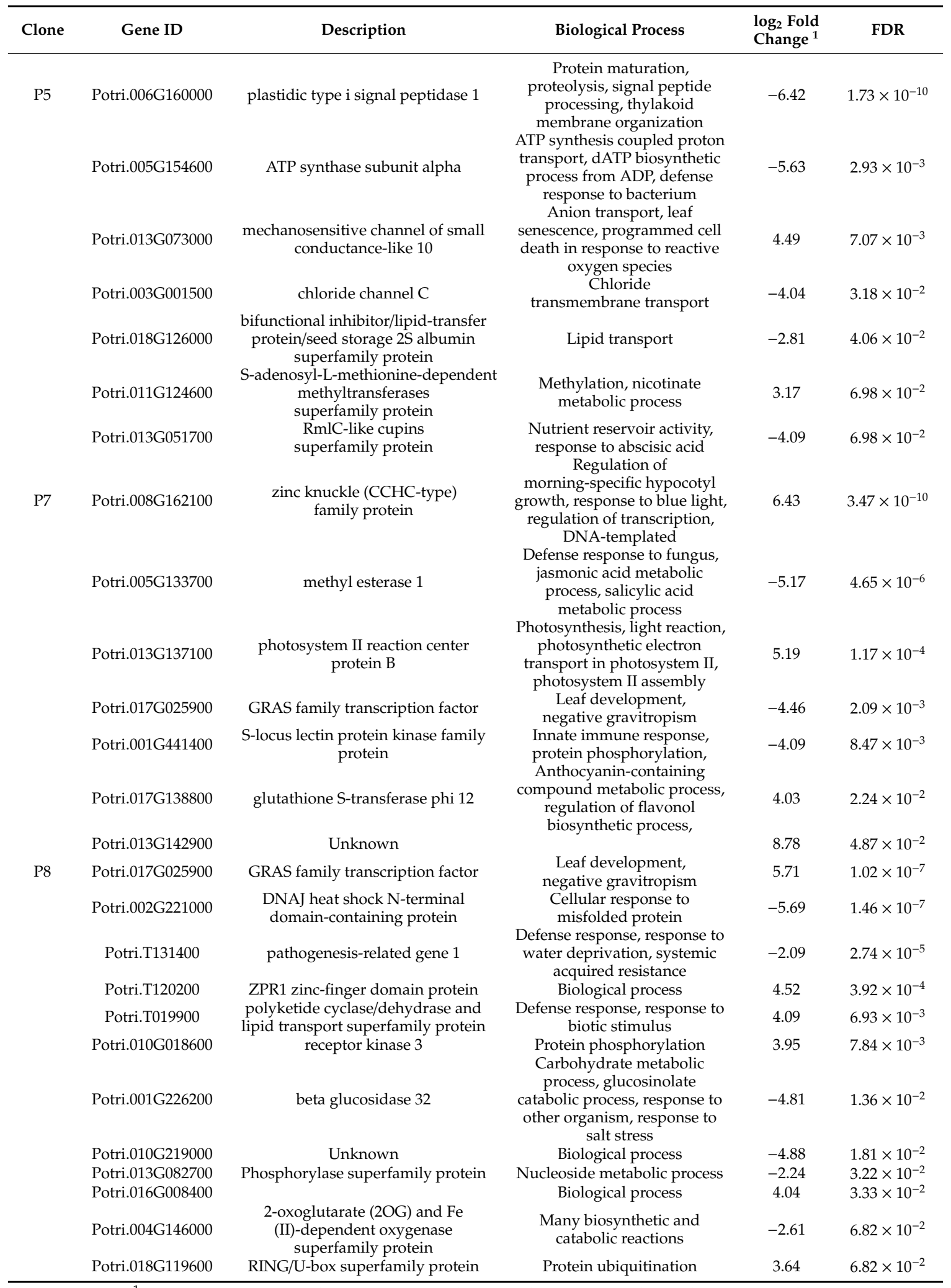

${ }^{1}$ Positive or negative values mean up- or downregulation in mixed samples, respectively.

The clone-specific differences in DEG numbers between Deppoldshausen and Reinshof were much stronger than in the total study site comparison. For clone P3, 1207 DEGs were found between the study sites, of which 685 genes showed higher expression levels in Reinhof and 522 in Deppoldshausen. 
For clones P5, P7 and P8, an opposite pattern was observed: about two-thirds of all DEGs between the study sites showed higher expression levels in Deppoldshausen than in Reinshof. A low number of genes in the total study site comparison and much higher gene numbers in the clone-specific comparisons showed that individual genotype has higher influence on the transcriptome response of plants than environmental conditions.

Table 3. Number of DEGs in comparisons between the study sites for each clone.

\begin{tabular}{cccc}
\hline Clone & Deppoldshausen & Reinshof & Total \\
\hline P3 & 522 & 685 & 1207 \\
P5 & 793 & 339 & 1132 \\
P7 & 1186 & 520 & 1706 \\
P8 & 835 & 442 & 1277 \\
\hline
\end{tabular}

\subsection{Quantitative Real-Time Reverse Transcription PCR (qRT-PCR)}

Two genes from the Kunitz trypsin inhibitor family PtiKPI-A1 (Potri.010G007700) and PtiKPI-A5 (Potri.010G007900) were selected for qRT-PCR of mixed samples to validate the RNA-seq data. The qRT-PCR confirmed expression profiles for all clones in the mixed RNA samples (Table S7).

\section{Discussion}

The aim of this study was to detect environmental effects on gene expression among poplar clones with different field performance and possible signs of interactions between poplar and black locust plants. The plots were established in April 2014. At the time of sampling in May 2016, plants had two years to adapt to the site conditions and develop sufficient root systems.

The use of relatively short $75 \mathrm{bp}$ long single-end reads in our study is well-justified by simulation and real-study experiments, which showed that $50 \mathrm{bp}$ reads were sufficient for good quality mapping and DEG detection and that results based on $75 \mathrm{bp}$ long reads were similar to those based on $100 \mathrm{bp}$ long reads [52,53]. Moreover, $50 \mathrm{bp}$ long reads and poplar transcriptome annotation from Phytozome were successfully used in poplar stress response studies [54,55].

It is interesting that reads of $P$. nigra $\times P$. maximowiczii hybrid P7 clone samples had better mapping to the P. trichocarpa transcriptome than reads of pure P. trichocarpa P8 clone, but the difference was not really great and was likely occasional due to high genetic similarity between these poplar species, especially P. maximowiczii and P. trichocarpa, which belong to the same Populus section, namely Tacamahaca [56].

The PCA analysis showed clear differences between the transcriptomes of hybrids, genotypes, study sites and type of stands (pure vs. mixed stands). All three hybrids were separated from each other based on their species background. The two clones of the P. maximowiczii $\times$ P. trichocarpa hybrid (P3 and P5) clustered together close to clone P7 (P. nigra $\times$ P. maximowiczii), while clone P8 (P. trichocarpa) was completely separated from the three other clones. Different poplar species and their hybrids have been successfully distinguished based on various phenotypic traits [57] and molecular markers, such as the chloroplast trnT-trnF region and nuclear rDNA sequencing [58], amplified fragment length polymorphisms (AFLPs) [59], microsatellites [60] and single nucleotide polymorphisms (SNPs) [61]. Our results demonstrated that a very clear taxonomic separation is also possible using transcriptome data. Two study sites, Reinshof and Deppoldshausen, were also clearly separated from each other for all hybrids. The weakest differentiation was observed between pure and mixed stands. Clones P3, P5 and P8 showed a similar pattern in the study site and type of stands clustering, but for clone P7, clear differences in separation of pure and mixed samples according to the study site were detected. The samples from Reinshof, as the site with favorable growing conditions, were almost overlapping. At the same time in Deppoldshausen, as the marginal growing site, very clear differences between pure and mixed samples were observed. This suggests that clone P7, despite of its best growing performance, is more sensitive to the growing conditions in comparison to other clones. In summary, 
the PCA analysis revealed that environmental conditions and genotypes had a more pronounced influence than the type of stand (pure vs. mixed) on differentiation between poplar clones at the transcriptome level, at least at this early stage of stand development.

The differential gene expression analysis based on the RNA-seq data was in agreement with the results of the PCA analysis. Total comparison between pure and mixed samples did not reveal any DEGs. This finding matched very well with basal area measurements and mortality data of poplar trees [35]. No significant differences in basal area between pure and mixed stands were observed. Likewise, total mortality data for poplar also showed no significant differences between mixed and pure stands in 2014-2015. However, significantly higher mortality in the mixture than in pure stands was detected to the end of 2016, which indicated increasing competition pressure of black locust. Only 30 genes showed significant differences in expression between pure and mixed samples for all four clones regardless of the study site (Table 2). DEGs involved in stress and defense response were observed for each clone. All of them showed lower expression levels in mixed samples. Previous studies showed that there seem to be universal stress response genes that always respond to any kind of stress [62,63]. Some studies demonstrated stress reduction in mixed stands during biotic [64] or abiotic [65] stress. Therefore, we hypothesize that the lower expression levels of stress and defense response genes in our mixed stands indicates that the slightly increased biodiversity (two species instead of one) already reduces stress to the plants. Mortality, growth and RNA-seq data together showed weak interaction between poplar and black locust, as a nitrogen-fixing species, in the first years of stand development (from 2014 until the start of 2016). Rooted seedlings of black locust were in advantage in growth over poplar trees that were planted as unrooted cuttings and had to develop a sufficient root system. Fertile soil conditions also promoted the growth of black locust and delayed development of interactions between both species, even in Deppoldshausen with its poorer than in Reinshof soil conditions. The same effect has been observed in studies with other $\mathrm{N}$-fixing species [66,67].

Reinshof and Deppoldshausen were clearly separated by 199 DEGs regardless of the type of clone or stand (Table S4), with more genes showing higher expression levels in Deppoldshausen. The clone comparisons for gene responses to contrasting study sites were in agreement with the results of the PCA. Deppoldhausen and Reinshof were clearly separated in their effects on gene expression in all clones and also demonstrated clonal differences (Table 3). About two-thirds of all DEGs between the study sites showed higher expression levels in Deppoldshausen than in Reinshof. Clone P7 had the highest number of DEGs, most of them showing higher expression levels in Deppoldshausen. Max 1 hybrid (P7) is known for its very good growing performance and high survival rates which might explain higher DEG values [36,37]. The marginal growing site Deppoldshausen provoked a stronger genetic response than the fertile growing site Reinshof. The separation between clones and sites has also been observed for DEGs in wood [32].

After two years of the stands' development, weak differences were still observed between pure and mixed stands and higher importance of growing sites for tree performance. The effects of species genetic background were the strongest. Based on this study, the clone Max 1 (P7) was selected as the most promising and interesting candidate for further transcriptome studies. According to our results, it combines the best growing performance with sensitivity to growing site conditions.

\section{Conclusions}

In this study, we report the first results on transcriptome analyses in poplar hybrids cultivated under different field conditions in pure stands and mixed with black locust stands. The results of the transcriptome analysis showed the clearest and the strongest differences between hybrids and genotypes of the same hybrid, followed by the study sites; the smallest differences were between types of stand. No DEGs were detected in the total comparison of pure and mixed stands as the result of high genetic clone specific variability of poplar clones. The small number of DEGs revealed for each clone in pure vs. mixed comparisons confirmed low interaction between poplar and black locust at 
that early stage of development, because it is likely that trees were too young, and their root systems had not formed any interactions in soil yet. There were 199 DEGs between the two study sites in total regardless of poplar clone or type of stands, which showed the importance of study site conditions for tree growth. The number of DEGs differed between clones depending on the study site. In general, the results indicate a strong influence of local environmental conditions and genotypes of clones on the performance of trees in pure and mixed stands at this early stage of the project. Further studies should be carried out with the samples based on preferably single clones to exclude genotype effects, but with a sufficient number of biological replicates for more detailed expression analysis.

Supplementary Materials: The following are available online at http://www.mdpi.com/1999-4907/11/10/1075/s1, Table S1: Plot design with eight poplar clones and three black locust provenances, Table S2: Kunitz trypsin inhibitor genes PtiKPI-A1 and PtiKPI-A5 and the corresponding PCR primers used for qRT-PCR validation, Table S3: The quality and quantity of sequenced reads for all samples before and after trimming, mapping and coverage values for all poplar samples, Table S4: List of 199 DEGs in the both study sites observed in all poplar clones and pure and mixed stands, Table S5: List of DEGs in Deppoldshausen for each clone in comparison between the study sites, Table S6: List of DEGs in Reinshof for each clone in comparison between the study sites, Table S7: Differences in expression based on RNA-seq and qRT-PCR of two genes from the Kunitz trypsin inhibitor family in mixed RNA samples between pure and mixed stands of different poplar clones in two study sites: Reinshof and Deppoldshausen, Figure S1: Air photo of the experimental plots in Reinshof and Deppoldshausen with four repetitions (Source: Google Map images, modified), Figure S2: Principal component analysis (PCA) based on annotated transcripts in 16 mixed poplar samples (A-fast mapping, B-default mapping and C—sensitive mapping).

Author Contributions: Conceptualization, L.L., A.P., K.V.K. and O.G.; formal analysis and investigation, O.K. and D.J.; writing—original draft preparation, O.K. and D.J.; writing—review and editing, L.L., A.P., K.V.K. and O.G.; supervision, L.L., K.V.K. and O.G.; project administration, L.L., A.P. and O.G.; funding acquisition, L.L., A.P. and O.G. All authors have read and agreed to the published version of the manuscript.

Funding: This research was funded by the German Federal Ministry of Education and Research (BMBF; FKZ 031A351C) within the framework of the IMPAC ${ }^{3}$ project ("Novel genotypes for mixed cropping allow for improved sustainable land use across arable land, grassland and woodland").

Acknowledgments: The authors thank Julia Beck for support during sequencing (Chronix Biomedical GmbH, Goettingen, Germany). We also thank Johanna Ropertz and Marco Winkler for the initial supervision of the plantations and sampling and Larissa Kunz for help in conducting the laboratory work.

Conflicts of Interest: The authors declare that they have no conflict of interest. The funders had no role in the design of the study; in the collection, analyses or interpretation of data; in the writing of the manuscript, or in the decision to publish the results.

\section{References}

1. Baltodano, J. Monoculture forestry: A critique from an ecological perspective. In Tree Trouble: A Compilation of Testimonies on the Negative Impact of Large-Scale Monoculture Tree Plantations, Proceedings of the 6th COP of the FCCC; Friends of the Earth International, Hague, the Netherlands, 13-15 November 2000; United Nations Climate Change: Bonn, Germany, 2000; pp. 2-10.

2. Bowyer, J. Forest plantations Threatening or Saving Natural Forests? Arborvitae 2006, 31, 8-9.

3. Morris, J.; Ningnan, Z.; Zengjiang, Y.; Collopy, J.; Daping, X. Water use by fast-growing Eucalyptus urophylla plantations in southern China. Tree Physiol. 2004, 24, 1035-1044. [CrossRef] [PubMed]

4. Liu, C.L.C.; Kuchma, O.; Krutovsky, K.V. Mixed-species versus monocultures in plantation forestry: Development, benefits, ecosystem services and perspectives for the future. Glob. Ecol. Conserv. 2018, 15, e00419. [CrossRef]

5. Benomar, L.; Des Rochers, A.; Larocque, G.R. Comparing growth and fine root distribution in monocultures and mixed plantations of hybrid poplar and spruce. J. For. Res. 2013, 24, 247-254. [CrossRef]

6. Pretzsch, H.; Block, J.; Dieler, J.; Dong, P.H.; Kohnle, U.; Nagel, J.; Spellmann, H.; Zingg, A. Comparison between the productivity of pure and mixed stands of Norway spruce and European beech along an ecological gradient. Ann. For. Sci. 2010, 67, 712. [CrossRef]

7. Pretzsch, H.; Dieler, J.; Seifert, T.; Rötzer, T. Climate effects on productivity and resource-use efficiency of Norway spruce (Picea abies [L.] Karst.) and European beech (Fagus sylvatica [L.]) in stands with different spatial mixing patterns. Trees Struct. Funct. 2012, 26, 1343-1360. [CrossRef] 
8. Pretzsch, H.; Schütze, G.; Uhl, E. Resistance of European tree species to drought stress in mixed versus pure forests: Evidence of stress release by inter-specific facilitation. Plant Biol. 2013, 15, 483-495. [CrossRef]

9. Marron, N.; Epron, D. Are mixed-tree plantations including a nitrogen-fixing species more productive than monocultures? For. Ecol. Manag. 2019, 441, 242-252. [CrossRef]

10. Sayyad, E.; Hosseini, S.M.; Mokhtari, J.; Mahdavi, R.; Jalali, S.G.; Akbarinia, M.; Tabari, M. Comparison of growth, nutrition and soil properties of pure and mixed stands of Populus deltoides and Alnus subcordata. Silva Fenn. 2006, 40, 27-35. [CrossRef]

11. Grünewald, H.; Böhm, C.; Quinkenstein, A.; Grundmann, P.; Eberts, J.; von Wühlisch, G. Robinia pseudoacacia L.: A lesser known tree species for biomass production. Bioenergy Res. 2009, 2, 123-133. [CrossRef]

12. Mantovani, D.; Veste, M.; Freese, D. Effects of Drought Frequency on Growth Performance and Transpiration of Young Black Locust (Robinia pseudoacacia L.). Int. J. For. Res. 2014, 2014, 1-11. [CrossRef]

13. Rédei, K.; Veperdi, I.; Meilby, H. Stand structure and growth of mixed white poplar (Populus alba L.) and black locust (Robinia pseudoacacia L.) plantations in Hungary. Acta Silv. Lignaria Hung. 2006, 2, $23-32$.

14. Tanaka-Oda, A.; Kenzo, T.; Koretsune, S.; Sasaki, H.; Fukuda, K. Ontogenetic changes in water-use efficiency $(\delta 13 \mathrm{C})$ and leaf traits differ among tree species growing in a semiarid region of the Loess Plateau, China. For. Ecol. Manag. 2010, 259, 953-957. [CrossRef]

15. Oliveira, N.; del Río, M.; Forrester, D.I.; Rodríguez-Soalleiro, R.; Pérez-Cruzado, C.; Cañellas, I.; Sixto, H. Mixed short rotation plantations of Populus alba and Robinia pseudoacacia for biomass yield. For. Ecol. Manag. 2018, 410, 48-55. [CrossRef]

16. Tuskan, G.A.; DiFazio, S.; Jansson, S.; Bohlmann, J.; Grigoriev, I.; Hellsten, U.; Putnam, M.; Ralph, S.; Rombauts, S.; Salamov, A.; et al. The genome of black cottonwood, Populus trichocarpa (Torr. \& Gray). Science 2006, 313, 1596-1604. [CrossRef]

17. Neale, D.B.; Kremer, A. Forest tree genomics: Growing resources and applications. Nat. Rev. Genet. 2011, 12, 111-122. [CrossRef]

18. Grattapaglia, D.; Plomion, C.; Kirst, M.; Sederoff, R.R. Genomics of growth traits in forest trees. Curr. Opin. Plant Biol. 2009, 12, 148-156. [CrossRef]

19. Cohen, D.; Bogeat-Triboulot, M.B.; Tisserant, E.; Balzergue, S.; Martin-Magniette, M.L.; Lelandais, G.; Ningre, N.; Renou, J.P.; Tamby, J.P.; Le Thiec, D.; et al. Comparative transcriptomics of drought responses in Populus: A meta-analysis of genome-wide expression profiling in mature leaves and root apices across two genotypes. BMC Genom. 2010, 11, 630. [CrossRef]

20. Gugger, P.F.; Peñaloza-Ramírez, J.M.; Wright, J.W.; Sork, V.L. Whole-transcriptome response to water stress in a California endemic oak, Quercus lobata. Tree Physiol. 2016, 37, 632-644. [CrossRef]

21. Hess, M.; Wildhagen, H.; Junker, L.V.; Ensminger, I. Transcriptome responses to temperature, water availability and photoperiod are conserved among mature trees of two divergent Douglas-fir provenances from a coastal and an interior habitat. BMC Genom. 2016, 17, 682. [CrossRef]

22. Janz, D.; Behnke, K.; Schnitzler, J.P.; Kanawati, B.; Schmitt-Kopplin, P.; Polle, A. Pathway analysis of the transcriptome and metabolome of salt sensitive and tolerant poplar species reveals evolutionary adaption of stress tolerance mechanisms. BMC Plant Biol. 2010, 10, 150. [CrossRef] [PubMed]

23. Lane, T.; Best, T.; Zembower, N.; Davitt, J.; Henry, N.; Xu, Y.; Koch, J.; Liang, H.; McGraw, J.; Schuster, S.; et al. The green ash transcriptome and identification of genes responding to abiotic and biotic stresses. BMC Genom. 2016, 17, 702. [CrossRef] [PubMed]

24. Müller, M.; Seifert, S.; Lübbe, T.; Leuschner, C.; Finkeldey, R. De novo transcriptome assembly and analysis of differential gene expression in response to drought in European beech. PLoS ONE 2017, 12, e0184167. [CrossRef] [PubMed]

25. Philippe, R.N.; Ralph, S.G.; Külheim, C.; Jancsik, S.I.; Bohlmann, J. Poplar defense against insects: Genome analysis, full-length cDNA cloning, and transcriptome and protein analysis of the poplar Kunitz-type protease inhibitor family. New Phytol. 2009, 184, 865-884. [CrossRef] [PubMed]

26. Li, Y.; Suontama, M.; Burdon, R.D.; Dungey, H.S. Genotype by environment interactions in forest tree breeding: Review of methodology and perspectives on research and application. Tree Genet. Genomes 2017, 13, 60. [CrossRef]

27. Rae, A.M.; Pinel, M.P.C.; Bastien, C.; Sabatti, M.; Street, N.R.; Tucker, J.; Dixon, C.; Marron, N.; Dillen, S.Y.; Taylor, G. QTL for yield in bioenergy Populus: Identifying G×E interactions from growth at three contrasting sites. Tree Genet. Genomes 2008, 4, 97-112. [CrossRef] 
28. Stape, J.L.; Binkley, D.; Ryan, M.G.; Fonseca, S.; Loos, R.A.; Takahashi, E.N.; Silva, C.R.; Silva, S.R.; Hakamada, R.E.; de Ferreira, J.M.A.; et al. The Brazil Eucalyptus Potential Productivity Project: Influence of water, nutrients and stand uniformity on wood production. For. Ecol. Manag. 2010, 259, 1684-1694. [CrossRef]

29. Marron, N.; Priault, P.; Gana, C.; Gérant, D.; Epron, D. Prevalence of interspecific competition in a mixed poplar/black locust plantation under adverse climate conditions. Ann. For. Sci. 2018, 75, 23. [CrossRef]

30. Izawa, T. Deciphering and prediction of plant dynamics under field conditions. Curr. Opin. Plant Biol. 2015, 24,87-92. [CrossRef]

31. Ning, K.; Ding, C.; Huang, Q.; Zhang, W.; Yang, C.; Liang, D.; Fan, R.; Su, X. Transcriptome profiling revealed diverse gene expression patterns in poplar (Populus $\times$ euramericana) under different planting densities. PLOS ONE 2019, 14, e0217066. [CrossRef]

32. Euring, D.; Janz, D.; Polle, A. Wood properties and transcriptional responses of poplar hybrids in mixed cropping with the nitrogen-fixing species Robinia pseudoacacia. Tree Physiol. 2020. in review.

33. Andersson, A.; Keskitalo, J.; Sjödin, A.; Bhalerao, R.; Sterky, F.; Wissel, K.; Tandre, K.; Aspeborg, H.; Moyle, R.; Ohmiya, Y.; et al. A transcriptional timetable of autumn senescence. Genome Biol. 2004, 5, R24. [CrossRef] [PubMed]

34. Lu, H.; Gordon, M.I.; Amarasinghe, V.; Strauss, S.H. Extensive transcriptome changes during seasonal leaf senescence in field-grown black cottonwood (Populus trichocarpa Nisqually-1). Sci. Rep. 2020, 10, 6581. [CrossRef] [PubMed]

35. Rebola-Lichtenberg, J.; Schall, P.; Annighöfer, P.; Ammer, C.; Leinemann, L.; Polle, A.; Euring, D. Mortality of different Populus genotypes in recently established mixed short rotation coppice with Robinia pseudoacacia L. Forests 2019, 10, 410. [CrossRef]

36. Schirmer, R.; Haikali, A. Sortenprüfung von Pappelhybriden für Energiewälder. LWF Wissen 2014, 74, 106-118.

37. Grotehusmann, H.; Janssen, A.; Haikali, A.; Hartmann, K.-U.; Hüller, W.; Karopka, M.; Schildbach, M.; Schirmer, R.; Schuppelius, T.; Töpfner, K. Pappelsortenprüfung im Projekt FastWOOD. Forstarchiv 2015, 86, 67-79. [CrossRef]

38. Goodstein, D.M.; Shu, S.; Howson, R.; Neupane, R.; Hayes, R.D.; Fazo, J.; Mitros, T.; Dirks, W.; Hellsten, U.; Putnam, N.; et al. Phytozome: A comparative platform for green plant genomics. Nucleic Acids Res. 2012, 40, 1178-1186. [CrossRef]

39. Chen, S.; Zhou, Y.; Chen, Y.; Gu, J. Fastp: An ultra-fast all-in-one FASTQ preprocessor. Bioinformatics 2018, 34, i884-i890. [CrossRef]

40. Urbanek, S.; Bibiko, H.-J.; Stefano, M.L. R: A Language and Environment for Statistical Computing. The R Foundation for Statistical Computing. Available online: http://www.r-project.org/ (accessed on 18 January 2018).

41. Langmead, B.; Salzberg, S.L. Fast gapped-read alignment with Bowtie 2. Nat. Methods 2012, 9, 357-359. [CrossRef]

42. Vu, V.Q. ggbiplot: A Ggplot2 Based Biplot. R Package, Version 0.55. Available online: http://github.com/ (accessed on 18 January 2018).

43. Robinson, M.D.; McCarthy, D.J.; Smyth, G.K. edgeR: A Bioconductor package for differential expression analysis of digital gene expression data. Bioinformatics 2009, 26, 139-140. [CrossRef]

44. Benjamini, Y.; Hochberg, Y. Controlling the False Discovery Rate: A Practical and Powerful Approach to Multiple Testing. J. R. Stat. Soc. Ser. B 1995, 57, 289-300. [CrossRef]

45. Ashburner, M.; Ball, C.A.; Blake, J.A.; Botstein, D.; Butler, H.; Cherry, J.M.; Davis, A.P.; Dolinski, K.; Dwight, S.S.; Eppig, J.T.; et al. Gene ontology: Tool for the unification of biology. Nat. Genet. 2000, 25, $25-29$. [CrossRef] [PubMed]

46. Huala, E.; Dickerman, A.W.; Garcia-Hernandez, M.; Weems, D.; Reiser, L.; LaFond, F.; Hanley, D.; Kiphart, D.; Zhuang, M.; Huang, W.; et al. The Arabidopsis Information Resource (TAIR): A comprehensive database and web-based information retrieval, analysis, and visualization system for a model plant. Nucleic Acids Res. 2001, 29, 102-105. [CrossRef] [PubMed]

47. Brunner, A.M.; Yakovlev, I.A.; Strauss, S.H. Validating internal controls for quantitative plant gene expression studies. BMC Plant Biol. 2004, 4, 14. [CrossRef] [PubMed]

48. Ye, J.; Coulouris, G.; Zaretskaya, I.; Cutcutache, I.; Rozen, S.; Madden, T.L. Primer-BLAST: A tool to design target-specific primers for polymerase chain reaction. BMC Bioinform. 2012, 13, 134. [CrossRef] 
49. Hall, T.A. BIOEDIT: A user-friendly biological sequence alignment editor and analysis program for Windows 95/98/NT. Nucleic Acids Symp. Ser. 1999, 41, 95-98.

50. Kibbe, W.A. OligoCalc: An online oligonucleotide properties calculator. Nucleic Acids Res. 2007, 35, 43-46. [CrossRef]

51. Livak, K.J.; Schmittgen, T.D. Analysis of relative gene expression data using real-time quantitative PCR and the $2^{-\Delta \Delta C T}$ method. Methods 2001, 25, 402-408. [CrossRef]

52. Chhangawala, S.; Rudy, G.; Mason, C.E.; Rosenfeld, J.A. The impact of read length on quantification of differentially expressed genes and splice junction detection. Genome Biol. 2015, 16, 131. [CrossRef]

53. Conesa, A.; Madrigal, P.; Tarazona, S.; Gomez-Cabrero, D.; Cervera, A.; McPherson, A.; Szcześniak, M.W.; Gaffney, D.J.; Elo, L.L.; Zhang, X.; et al. A survey of best practices for RNA-seq data analysis. Genome Biol. 2016, 17, 13. [CrossRef]

54. Barghini, E.; Cossu, R.M.; Cavallini, A.; Giordani, T. Transcriptome analysis of response to drought in poplar interspecific hybrids. Genom. Data 2015, 3, 143-145. [CrossRef] [PubMed]

55. Jia, J.; Zhou, J.; Shi, W.; Cao, X.; Luo, J.; Polle, A.; Luo, Z. Bin Comparative transcriptomic analysis reveals the roles of overlapping heat-/drought-responsive genes in poplars exposed to high temperature and drought. Sci. Rep. 2017, 7, 43215. [CrossRef] [PubMed]

56. Eckenwalder, J.E. Systematics and evolution of Populus. In Biology of Populus and Its Implications for Management and Conservation; Stettler, R.F., Bradshaw, H.D., Heilman, P.E., Hinckley, T.M., Eds.; NRC Research Press: Montreal, QC, Canada, 1996; pp. 7-32.

57. Verlinden, M.S.; Broeckx, L.S.; Van den Bulcke, J.; Van Acker, J.; Ceulemans, R. Comparative study of biomass determinants of 12 poplar (Populus) genotypes in a high-density short-rotation culture. For. Ecol. Manag. 2013, 307, 101-111. [CrossRef]

58. Hamzeh, M.; Dayanandan, S. Phylogeny of Populus (Salicaceae) based on nucleotide sequences of chloroplast trnT-trnF region and nuclear rDNA. Am. J. Bot. 2004, 91, 1398-1408. [CrossRef]

59. Cervera, M.T.; Storme, V.; Soto, A.; Ivens, B.; Van Montagu, M.; Rajora, O.P.; Boerjan, W. Intraspecific and interspecific genetic and phylogenetic relationships in the genus Populus based on AFLP markers. Theor. Appl. Genet. 2005, 111, 1440-1456. [CrossRef]

60. Liesebach, H.; Schneck, V.; Ewald, E. Clonal fingerprinting in the genus Populus L. by nuclear microsatellite loci regarding differences between sections, species and hybrids. Tree Genet. Genomes 2010, 6, 259-269. [CrossRef]

61. Isabel, N.; Lamothe, M.; Thompson, S.L. A second-generation diagnostic single nucleotide polymorphism (SNP)-based assay, optimized to distinguish among eight poplar (Populus L.) species and their early hybrids. Tree Genet. Genomes 2013, 9, 621-626. [CrossRef]

62. Rasmussen, S.; Barah, P.; Suarez-Rodriguez, M.C.; Bressendorff, S.; Friis, P.; Costantino, P.; Bones, A.M.; Nielsen, H.B.; Mundy, J. Transcriptome responses to combinations of stresses in Arabidopsis. Plant Physiol. 2013, 161, 1783-1794. [CrossRef]

63. Sham, A.; Moustafa, K.; Al-Ameri, S.; Al-Azzawi, A.; Iratni, R.; AbuQamar, S. Identification of Arabidopsis candidate genes in response to biotic and abiotic stresses using comparative microarrays. PLoS ONE 2015, 10, e0125666. [CrossRef]

64. Wolfe, M.S. The Current Status and Prospects of Multiline Cultivars and Variety Mixtures for Disease Resistance. Annu. Rev. Phytopathol. 1985, 23, 251-273. [CrossRef]

65. Schäfer, C.; Grams, T.E.E.; Rötzer, T.; Feldermann, A.; Pretzsch, H. Drought stress reaction of growth and $\delta 13 \mathrm{C}$ in tree rings of European beech and Norway spruce in monospecific versus mixed stands along a precipitation gradient. Forests 2017, 8, 177. [CrossRef]

66. Radosevich, S.R.; Hibbs, D.E.; Ghersa, C.M. Effects of species mixtures and growth and stand development of Douglas-fir and red alder. Can. J. For. Res. 2006, 36, 768-782. [CrossRef]

67. Forrester, D.; Bauhus, J.; Cowie, A. On the success and failure of mixed-species tree plantations: Lessons learned from a model system of Eucalyptus globulus and Acacia mearnsii. For. Ecol. Manag. 2005, 209, 147-155. [CrossRef]

(C) 2020 by the authors. Licensee MDPI, Basel, Switzerland. This article is an open access article distributed under the terms and conditions of the Creative Commons Attribution (CC BY) license (http://creativecommons.org/licenses/by/4.0/). 